\title{
Catalytic wet peroxide oxidation of formic acid in wastewater with naturally-occurring iron ore
}

\author{
E Erasmus ${ }^{1 *}$, JO Claassen ${ }^{2}$ and WA van der Westhuizen ${ }^{2}$ \\ 'Department of Chemistry, University of the Free State, Bloemfontein, 9300, Republic of South Africa \\ ${ }^{2}$ Department of Geology, University of the Free State, Bloemfontein, 9300, Republic of South Africa
}

\begin{abstract}
The catalytic wet oxidation of formic acid, using hydrogen peroxide as the oxidizing agent over naturally-occurring iron ore, was explored. Firstly, the decomposition of hydrogen peroxide to its hydroxyl radicals (HO* and HOO*) over naturally-occurring iron ore was investigated. The reaction was monitored by ATR FTIR by following the disappearance of the $\mathrm{O}-\mathrm{H}$ peak of $\mathrm{H}_{2} \mathrm{O}_{2}$ at $2860 \mathrm{~cm}^{-1}$. Decomposition occurred according to the Fenton mechanism and resulted in observed first-order rate constants one order of magnitude faster than that without the catalyst. Turnover frequencies (TOF) of 1.97-8.85 $\times 10^{-9} \mathrm{~s}^{-1}$ were obtained for the decomposition of $\mathrm{H}_{2} \mathrm{O}_{2}$. The wet oxidation of formic acid using hydrogen peroxide as the oxidizing agent over naturally-occurring iron ore reaction was also monitored by ATR FTIR, following the disappearance of the carbonyl stretching frequency of formic acid at $1727 \mathrm{~cm}^{-1}$. Experiments were performed at different hydrogen peroxide $(2,4,6$ and $8 \mathrm{M})$ and formic acid $(1.26,2.52,6.3$ and $12.6 \mathrm{M})$ concentrations as well as with varying amounts of naturally-occurring iron ore catalyst, at $\mathrm{pH}=2$. Elevated hydrogen peroxide and formic acid concentrations led to increased observed first-order kinetics, as high as $k_{\text {obs }}=21.75 \times 10^{-4} \mathrm{~min}^{-1}$ with a TOF $=1.73 \mathrm{x}$ $10^{-8}-1.12 \times 10^{-6} \mathrm{~s}^{-1}$
\end{abstract}

Keywords: iron ore, catalytic wet oxidation, formic acid, Fenton, hydrogen peroxide

\section{INTRODUCTION}

Apart from the large-scale exploitation of iron containing ore as raw material feed for iron extraction, it is one of the few naturally-occurring minerals that have been exploited for alternative applications. As a result, numerous studies report on the use of iron-containing minerals as adsorbents (Nowack et al., 2006; Rovira et al., 2008; Zeng et al., 2004; Spiteri et al., 2008; Guo et al., 2007; Zhang et al., 2004; Pirillo et al., 2009) and catalysts (Costa et al., 2008; Huang et al., 2000; Centi et al., 2000; Andreozzi et al., 2003; Du et al., 2008) for the removal of pollutants from wastewaters.

Formic acid is a pollutant in wastewater from the effluents of some industries (Claudel et al., 1984). It is also a stable intermediate from the decomposition of many organic pollutants (Chou et al., 1998; Davis et al., 1999; Hwang et al., 1999; Dinsdale et al., 2000), which is difficult to oxidize further (Ogata et al., 1981; Harmsen et al., 1997). For this reason, formic acid is often used as a model organic pollutant in wastewater treatment studies (Kawaguchi et al., 1993; Kim et al., 1996; Butterfield et al., 1997; Candal et al., 1997; Miller et al., 1999).

Wet air oxidation is a procedure commonly used to reduce the total organic carbon (TOC) in industrial wastewater (Matatov-Meytal et al., 1998; Mishra et al., 1995; Levec et al., 1995; Luck et al., 1996; Gallezot et al., 1997; Klinghoffer et al., 1998; Romalho et al., 1983.). The reaction however requires high operating temperatures. The use of oxidation agents allows the process to precede at lower reaction temperatures. Ozone and hydrogen peroxide $\left(\mathrm{H}_{2} \mathrm{O}_{2}\right)$ are the preferred oxidants. These compounds are active even at room temperature and decompose to environmentally friendly $\mathrm{O}_{2}$ and $\mathrm{H}_{2} \mathrm{O}$.

\footnotetext{
* To whom all correspondence should be addressed. $\widetilde{\Phi}+2751$ 401-9656 / +27 62704 6350; e-mail: erasmuse@ufs.ac.za Received 20 July 2015; accepted in revised form 3 June 2016
}

Water treatment with ozone is well known (Masten et al., 1994; Luck et al., 1997; Allemane et al., 1993; Andreozzi et al., 1996). Its effectiveness is however limited by lower solubility at atmospheric pressure and the short lifetime of ozone renders the process more expensive. $\mathrm{H}_{2} \mathrm{O}_{2}$ is therefore the preferred oxidant.

The use of hydrogen peroxide to oxidize the pollutants in wastewater requires it to be in its radical form. The production of hydroxyl radicals from $\mathrm{H}_{2} \mathrm{O}_{2}$ and minimization of its decomposition to water is achieved either photochemically or by catalysis. The photochemical activation of hydrogen peroxide requires UV-radiation. However, due to its low extinction coefficient, the operation process is costly (Ojima et al., 1994). The formation of the hydroxyl radicals using iron ion catalysis is well known (Edwards et al., 1992; Walling et al., 1975). The process proceeds according to the Fenton mechanism as illustrated below (Centi et al., 2000):

$$
\begin{aligned}
& \mathrm{Fe}^{2+}+\mathrm{H}_{2} \mathrm{O}_{2} \rightarrow \mathrm{Fe}^{3+}+\mathrm{OH}^{-}+\mathrm{HO}^{\circ} \\
& \mathrm{Fe}^{3+}+\mathrm{H}_{2} \mathrm{O}_{2} \rightarrow \mathrm{Fe}^{2+}+\mathrm{H}^{+}+\mathrm{HOO}^{\circ}
\end{aligned}
$$

Numerous examples are available for the oxidation of different organic pollutants in wastewater, using a combination of iron ion and hydrogen peroxide. There are however very few publications available on the use of naturally-occurring iron ore (such as hematite, ferrihydrite, goethite and lepidocrocite) as a cheap alternative for the oxidation of pollutants such as formic acid in wastewater.

This study utilizes hard high-grade hematite ore as such an alternative. The ore is massive Gamagaran type ore from the Sishen Iron Formation in the Northern Cape Province of the Republic of South Africa. It comprises sand to silt size hematite grains in a matrix which appears as ferruginized, hematitic sandstone and shale. Small amounts of specular hematite are also present (Wilson et al., 1998). 


\section{EXPERIMENTAL}

\section{Chemicals and instruments}

The hematite ore used in this study was sourced from Sishen Iron Ore Mine (see Fig. 1). The hematite was crushed and screened with only the particles in the size range $75-212 \mu \mathrm{m}$ used. All reagents (Merck, Sigma-Aldrich) were used without further purification and water was double distilled. Attenuated total reflectance Fourier transform infrared (ATR FTIR) spectra were recorded on a Nicolet IS 50 infrared spectrophotometer equipped with a diamond ATR. X-ray photoelectron spectroscopy (XPS) data were recorded on a PHI 5000 Versaprobe system, with monochromatic $\mathrm{Al} \mathrm{Ka} \mathrm{X-ray} \mathrm{source.} \mathrm{Spectra} \mathrm{were}$ obtained, using the aluminium anode $(\mathrm{Al} \mathrm{Ka}=1486.6 \mathrm{eV})$, operating at $50 \mu \mathrm{m}, 12.5 \mathrm{~W}$ and $15 \mathrm{kV}$ energy. The survey scans were recorded at constant pass energy of $187.85 \mathrm{eV}$. The detailed regional scans were recorded at constant pass energy of $29.35 \mathrm{eV}$ and analyser resolution of $\leq 0.5 \mathrm{eV}$. The background pressure was $2 \times 10^{-8} \mathrm{~Pa}$. The XPS data were analysed with Multipak version 8.2c computer software (Moulder et al., 1995), applying Gaussian-Lorentz fits (the Gaussian/Lorentz ratios were always $>95 \%)$. The iron ore were characterized by X-ray diffraction (XRD) using a Panalytical Empyrean diffractometer for elemental analysis.

\section{Hydrogen peroxide decomposition test without the catalyst}

$2 \mathrm{M}$ hydrogen peroxide solutions in water were prepared according to Table 2, while stirring at room temperature. The $\mathrm{pH}$ was adjusted with the addition of either $\mathrm{H}_{2} \mathrm{SO}_{4}$ or $\mathrm{NaOH}$ similar to published procedures $(\mathrm{Li}, 1999)$. The final test volume was $10 \mathrm{~mL}$. Samples were taken at regular intervals and analysed by ATR FTIR.

\section{Hydrogen peroxide decomposition test with the naturally- occurring iron ore added as catalyst}

Hydrogen peroxide reaction mixtures of different concentrations $(2,4,6$ and $8 \mathrm{M})$ were prepared in water according to Table 2, while stirring at room temperature. After the $\mathrm{pH}$ was adjusted with the addition of $\mathrm{H}_{2} \mathrm{SO}_{4}$ to obtain a $\mathrm{pH}$ of 2, $20 \mathrm{mg}$ crushed $\mathrm{Fe}_{2} \mathrm{O}_{3}$ ore was added to the reaction mixture. Samples were taken at regular intervals and analysed by ATR FTIR.

\section{Hydrogen peroxide decomposition and formic acid oxidation test with $\mathrm{Fe}_{2} \mathrm{O}_{3}$ catalyst}

Reaction mixtures $(10 \mathrm{~mL})$ were prepared according to Table 3 , while stirring at $35^{\circ} \mathrm{C}$. After the $\mathrm{pH}$ was adjusted to 2 with the addition $\mathrm{H}_{2} \mathrm{SO}_{4}$, the required amounts of formic acid and $\mathrm{Fe}_{2} \mathrm{O}_{3}$ catalyst (iron ore) were added. Samples were taken at regular intervals and analysed by ATR FTIR.

Turnover frequencies (TOF) were determined by the following equation:

$\left.\mathrm{TOF}=\frac{\left[\frac{\text { Moles formic acid converted }}{\text { Moles of } \mathrm{F}_{\mathrm{e}} 2 \mathrm{O}_{3}}\right.}{\text { Time }(\mathrm{s})}\right]$

In addition, pseudo first-order rate constants, $k_{\mathrm{obs}}$, were calculated by fitting kinetic data to the first-order equation

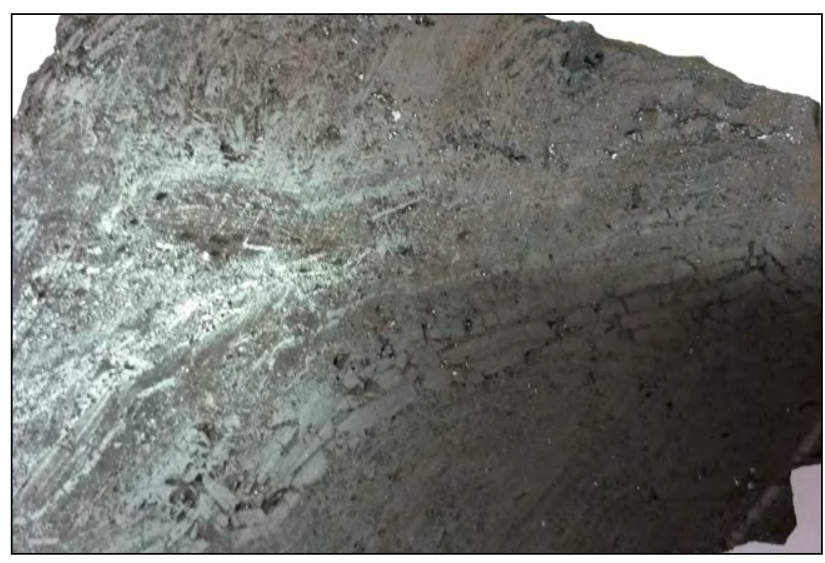

Figure 1

A photograph of hematite ore (prior to crushing) utilized for the wet oxidation reaction

(Espenson, 1995) $[A] t=[A]_{0} \mathrm{e}^{\left(-k^{\text {obs }} t\right)}$ with $[A] t$ and $[A]_{0}$ the absorbance of the indicated species at time $t$ and at $t=0$.

\section{Preliminary stability testing of the natural iron ore}

A $50 \mathrm{mg}$ sample of the naturally-occurring iron ore was stirred in a solution of $4 \mathrm{M}$ hydrogen peroxide at $\mathrm{pH} 2$ for 10 days. This test showed that no iron leaching occurred during the time period, which was the same as was used for the catalytic testing.

\section{RESULTS AND DISCUSSION}

\section{Chemical analysis of the iron ore}

$\mathrm{XRD}$ analysis of the iron ore revealed that the sample contains $98.13 \% \mathrm{Fe}_{2} \mathrm{O}_{3}, 0.45 \% \mathrm{Al}_{2} \mathrm{O}_{3}$ and $1.12 \% \mathrm{SiO}_{2}$.

\section{X-ray photoelectron spectroscopy}

The XPS spectra of the iron ore (Fig. 2) revealed that the sample contained $\mathrm{Fe}, \mathrm{O}, \mathrm{C}$ (possibly from $\mathrm{CaCO}_{3}$ ) and $\mathrm{Si}$. Table 1 summarizes the atomic percentages and binding energies $(\mathrm{eV})$ of these elements. XPS samples most often exhibit adventitious carbon contamination which is detected by XPS analysis (Castaneda et al., 2010; Kyotani et al., 1997). The binding energy of these carbonaceous deposits is set at $284.9 \mathrm{eV}$ and the other element's binding energies are referenced against it. The detected silicon is most probably from mineral contaminants such as quartz, as indicated by the XRD analysis.

The binding energy of the Fe $2 \mathrm{p}_{3 / 2}$ (see Fig. 2 right) was detected at $710.8 \mathrm{eV}$, which is in agreement with published values of $710.8 \mathrm{eV}$ for $\mathrm{Fe}_{2} \mathrm{O}_{3}$ (Brion, 1980; Nefedov et al., 1975). The detailed scan of the oxygen 1s area (see Fig. 2 right) showed that there are two distinct peaks present. The peak observed at $531.5 \mathrm{eV}$, which accounts for $85.7 \%$ of the oxygen present in the sample, is from adsorbed oxygen and other adventitious sources, normally present in all samples. The peak observed at $529.3 \mathrm{eV}$, which accounts for $14.3 \%$ of the oxygen present, is allocated to oxygen present in iron oxide $\mathrm{Fe}_{2} \mathrm{O}_{3}$. When calculated, the peak at $529.3 \mathrm{eV}$ accounts for $4.3 \%$ of the total atomic percentage. This value is in agreement with the amount of oxygen expected if the iron content in $\mathrm{Fe}_{2} \mathrm{O}_{3}$ is $2.8 \%$. The binding energy of the $\mathrm{O} 1 \mathrm{~s}$ $(529.3 \mathrm{eV})$ in $\mathrm{Fe}_{2} \mathrm{O}_{3}$, is in close agreement with published values of 529.5 and $529.6 \mathrm{eV}$ for $\mathrm{Fe}_{2} \mathrm{O}_{3}$ (Haber et al., 1976; Nefedov et al., 1977). 


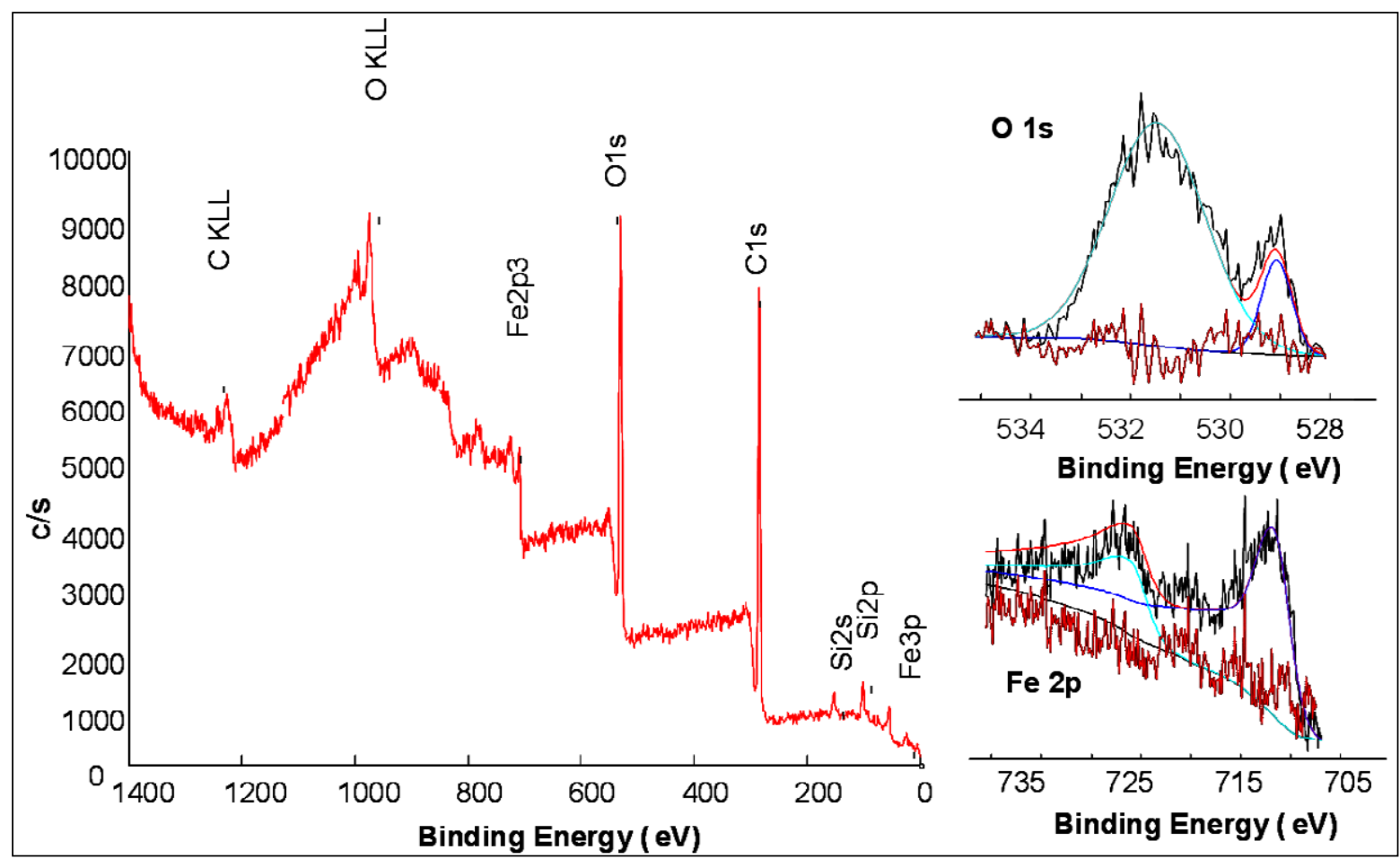

Figure 2

Left: Wide scan XPS spectra of hematite iron ore $\left(\mathrm{Fe}_{2} \mathrm{O}_{3}\right)$. Right: Detailed scan of the $1 \mathrm{~s} \mathrm{O}$ peaks and the detailed scan of the $2 p$ Fe peak.

\section{Decomposition of hydrogen peroxide}

Hydrogen peroxide is a thermodynamically unstable compound that decomposes to form oxygen and water. Various factors influence the rate of decomposition, including temperature and $\mathrm{pH}$. The decomposition of hydrogen peroxide is enhanced when catalysts such as $\mathrm{Pt}$ and $\mathrm{MnO}_{2}$ are added (Petrucci, 2007). However when certain metal ions, including $\mathrm{Fe}^{2+}$, are used as a catalyst the decomposition proceeds according to the Fenton mechanism to produce the free radicals $\mathrm{HO}^{*}$ and $\mathrm{HOO}^{\circ}$.

Since this study is concerned with the decomposition of hydrogen peroxide using naturally-occurring iron ore, it is also important to investigate the decomposition of hydrogen peroxide in the absence of iron ore.

Figure 3 shows the comparative ATR FTIR graphs of hydrogen peroxide, water, a 1:1 mixture of hydrogen peroxide and water, and an $8 \mathrm{M}$ hydrogen peroxide solution in water. The distinctive frequencies associated with water are the - $\mathrm{OH}$ bending frequency at $1646 \mathrm{~cm}^{-1}$ and the $-\mathrm{OH}$ stretching frequency in the area $2800-3800 \mathrm{~cm}^{-1}$. Hydrogen peroxide shows 4 peaks: $1370,1646,2860 \mathrm{~cm}^{-1}$, and $2800-3800 \mathrm{~cm}^{-1}$. These peaks are assigned to the asymmetric deformation band of $\mathrm{H}_{2} \mathrm{O}_{2}\left(v_{1}\right)$, the -OH bending $\left(v_{2}\right)$, a combination of $v_{1}, v_{2}$ and $v_{3}$, and the -OH stretching frequency $\left(v_{3}\right)$, respectively. These assignments are in agreement with published data from Giguere (1950). The peak observed at $2860 \mathrm{~cm}^{-1}$ was used to follow the decomposition of hydrogen peroxide.

The decomposition of $2 \mathrm{M}$ hydrogen peroxide solutions in water was followed by ATR FTIR at different $\mathrm{pH}$ levels. Figure 4 shows the ATR FTIR spectra of the decomposition of a $2 \mathrm{M}$ solution of hydrogen peroxide in water at a $\mathrm{pH}$ of 9. It is known from literature that hydrogen peroxide is more stable at lower $\mathrm{pH}$ levels, as indicated in Table 2. Thus the rest of the experiments were conducted at a $\mathrm{pH}$ of 2 to keep self-decomposition to a minimum.

\begin{tabular}{|c|c|c|c|c|}
\hline \multicolumn{5}{|c|}{$\begin{array}{c}\text { TABLE } 1 \\
\begin{array}{l}\text { Atomic percentages and binding energies of the different } \\
\text { elements present in the iron ore (hematite) }\end{array}\end{array}$} \\
\hline & C 1s & $01 \mathrm{~s}$ & Si $2 p$ & Fe 2p \\
\hline $\begin{array}{l}\text { Atomic } \\
\%\end{array}$ & 66.0 & 29.8 & 1.5 & 2.8 \\
\hline $\begin{array}{l}\text { Binding } \\
\text { energy } \\
\text { (eV) }\end{array}$ & 284.9 & $\begin{array}{l}529.3\left(\mathrm{Fe}_{2} \mathrm{O}_{3}\right)-14.3 \% \\
531.5 \text { (other })-85.7 \%\end{array}$ & 102.8 & $\begin{array}{l}710.8\left(2 p_{3 / 2}\right)-66.6 \% \\
724.0\left(2 p_{1 / 2}\right)-33.4 \%\end{array}$ \\
\hline
\end{tabular}

TABLE 2

The observed rate constants of the decomposition of hydrogen peroxide with and without the iron ore powder at different concentrations and $\mathrm{pH}$ levels

\begin{tabular}{|c|c|c|c|}
\hline \multicolumn{4}{|c|}{ different concentrations and pH levels } \\
\hline \multicolumn{3}{|c|}{$\mathbf{H}_{2} \mathbf{O}_{2}$ decomposition without iron ore powder } \\
\hline$\left[\mathrm{H}_{2} \mathrm{O}_{2}\right]$ & $\mathrm{pH}$ & \multicolumn{2}{|c|}{$k_{\mathrm{obs}} \times 10^{6} \mathrm{~min}^{-1}$} \\
\hline $2 \mathrm{M}$ & 2 & \multicolumn{2}{|c|}{$6.47(1.3)$} \\
\hline $2 \mathrm{M}$ & 4 & \multicolumn{2}{|c|}{$7.08(1.2)$} \\
\hline $2 \mathrm{M}$ & 6 & \multicolumn{2}{|c|}{$7.78(1.7)$} \\
\hline $2 \mathrm{M}$ & 9 & \multicolumn{2}{|c|}{$8.44(2.2)$} \\
\hline \multicolumn{4}{|c|}{$\mathbf{H}_{2} \mathbf{O}_{2}$ decomposition with iron ore powder } \\
\hline$\left[\mathrm{H}_{2} \mathrm{O}_{2}\right]$ & $\mathrm{pH}$ & $k_{\mathrm{obs}} \times 10^{5} \mathrm{~min}^{-1}$ & $\mathrm{TOF} \mathrm{s}$ \\
\hline $2 \mathrm{M}$ & 2 & $1.09(0.3)$ & $1.97 \times 10^{-9}$ \\
\hline $4 \mathrm{M}$ & 2 & $1.08(0.4)$ & $3.93 \times 10^{-9}$ \\
\hline $6 \mathrm{M}$ & 2 & $1.06(0.4)$ & $5.89 \times 10^{-9}$ \\
\hline $9 \mathrm{M}$ & 2 & $1.03(0.5)$ & $8.85 \times 10^{-9}$ \\
\hline
\end{tabular}

The decomposition of hydrogen peroxide solutions of different concentrations $(2,4,6$ and $8 \mathrm{M})$ were followed by ATR FTIR at $\mathrm{pH}=2$ in the presence of naturally-occurring iron ore $\left(\mathrm{Fe}_{2} \mathrm{O}_{3}\right)$.

Figure 5 depicts the ATR FTIR spectra of the decomposition of an $8 \mathrm{M}$ solution of hydrogen peroxide in water at a $\mathrm{pH}$ of 2 in the presence of a catalytic amount $(20 \mathrm{mg})$ of naturallyoccurring iron ore. 
The observed rate constants obtained for the different concentrations of hydrogen peroxide (see Table 2) are, within experimental conditions, the same, at approx. $1.0 \times 10^{-5} \mathrm{~min}^{-1}$. This is approximately one order of magnitude larger than values observed for the decomposition of hydrogen peroxide in the absence of iron ore. The slower than expected rate of decomposition of the hydrogen peroxide in the presence of the iron ore can be attributed to, firstly, the small amount of active catalyst (the small amount of $\mathrm{Fe}_{2} \mathrm{O}_{3}$ at the surface of the powdered sample available for catalysis). Secondly, it is known that iron in its oxide form is a more ineffective catalyst for the decomposition of hydrogen peroxide than other iron ions such as $\mathrm{FeCl}_{2}, \mathrm{FeCl}_{3}$, $\mathrm{Fe}\left(\mathrm{NO}_{3}\right)_{3}$, etc. Lastly, the low solubility of the iron ore at the chosen conditions affects diffusion during the reaction.

Iron oxide may be a relatively slow catalyst for the decomposition of hydrogen peroxide. Since the aim of the study is to catalytically oxidize formic acid using the hydroxyl radical, fast decomposition of the hydrogen peroxide is not required.

The observed rate of hydrogen peroxide decomposition over naturally-occurring iron ore (measured in this study) compares well with studies conducted on hematite $\left(0.9 \times 10^{-5} \mathrm{~min}^{-1}\right)$ and other iron-containing catalysts reported in literature (Huang et al., 2001).

\section{Catalytic wet oxidation of formic acid}

Figure 6 depicts the comparative ATR FTIR graphs of formic acid and a variety of different concentrations $(2,4,6$ and $8 \mathrm{M})$ of formic acid dissolved in water at $\mathrm{pH}=2$. The arrows (in the bottom spectra) indicate how the peaks increase or decrease as the concentration of the formic acid is increased. The distinctive frequencies observed for formic acid dissolved in water appear at 2 856, 1727,1413 and $1200 \mathrm{~cm}^{-1}$, representing the $\mathrm{C}-\mathrm{H}$ stretching frequency $(v \mathrm{C}-\mathrm{H})$, the $\mathrm{C}=\mathrm{O}$ stretching frequency $(v \mathrm{C}=\mathrm{O})$ and the two $\mathrm{CH}_{2}$ bending frequency $\left(\omega \mathrm{CH}_{2}\right)$, respectively. These assignments were made in agreement with published data from Popova et al. (2000).

Since the C-H stretching frequency of formic acid overlaps with the distinctive combination peaks $\left(v_{1}, v_{2}\right.$ and $\left.v_{3}\right)$ of $\mathrm{H}_{2} \mathrm{O}_{2}$ at $2860 \mathrm{~cm}^{-1}$, the $\mathrm{C}=\mathrm{O}$ stretching frequency at $1727 \mathrm{~cm}^{-1}$ was used to follow the oxidation of formic acid in the following experiments.

The wet oxidation of formic acid by decomposed hydrogen peroxide radicals ( $\mathrm{HO}^{*}$ and $\mathrm{HOO}^{*}$ ) over naturally-occurring iron ore solutions was followed by ATR FTIR using different concentrations of hydrogen peroxide $(2,4,6$ and $8 \mathrm{M})$ and formic acid $(1.26,2.52,6.3$ and $12.6 \mathrm{M})$ as well as varying amounts of $\mathrm{Fe}_{2} \mathrm{O}_{3}$ catalyst at $\mathrm{pH}=2$. Figure 7 shows the ATR FTIR spectra of the wet oxidation of an $8 \mathrm{M}$ formic acid solution by the hydroxyl radicals ( $\mathrm{HO}^{*}$ and $\mathrm{HOO}^{\circ}$ ) from decomposed $2 \mathrm{M} \mathrm{H}_{2} \mathrm{O}_{2}$ in water at a $\mathrm{pH}$ of 2 in the presence of a catalytic amount of naturallyoccurring iron ore. The different experimental conditions and its observed first-order rate constants are presented in Table 3. These observed rate constants are two orders of magnitude larger than that observed for the decomposition of hydrogen peroxide. This could be attributed to an increased amount of catalyst used and the formation of two hydroxyl radicals that can react with the formic acid.

From Table 3 (Experiments A1-A6) and Fig. 8, it is evident that the decomposition rate increases with an increase in the hydrogen peroxide concentration. This is expected since higher concentrations of hydrogen peroxide will result in the formation of more hydroxyl radicals, which in turn would oxidize the formic acid faster.

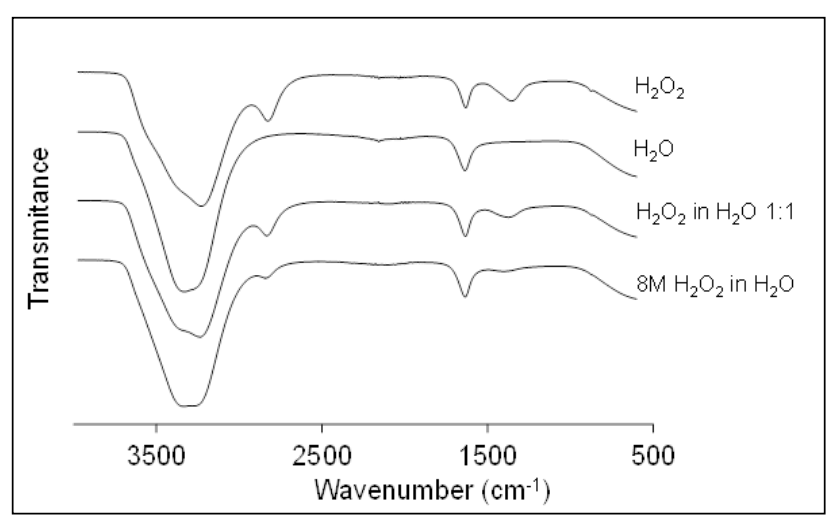

Figure 3

A comparative graph showing the ATR FTIR of hydrogen peroxide, water, a 1:1 mixture of hydrogen peroxide and water, and a $8 M$ hydrogen peroxide solution in water

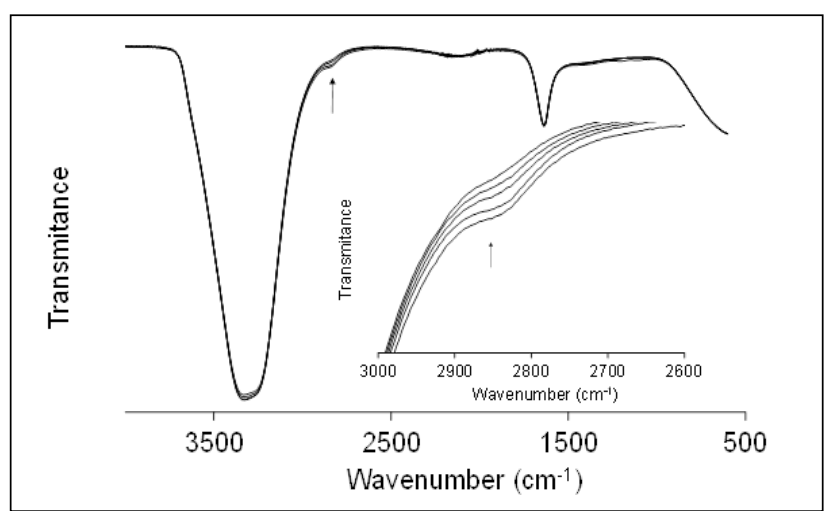

Figure 4

ATR FTIR spectra of a $2 \mathrm{M}$ solution of $\mathrm{H}_{2} \mathrm{O}_{2}$ decomposing in water at a $\mathrm{pH}$ of 9. Insert: Enlarged area at 2600 to $3000 \mathrm{~cm}^{-1}$ showing the disappearance of the peak at $2860 \mathrm{~cm}^{-1}$.

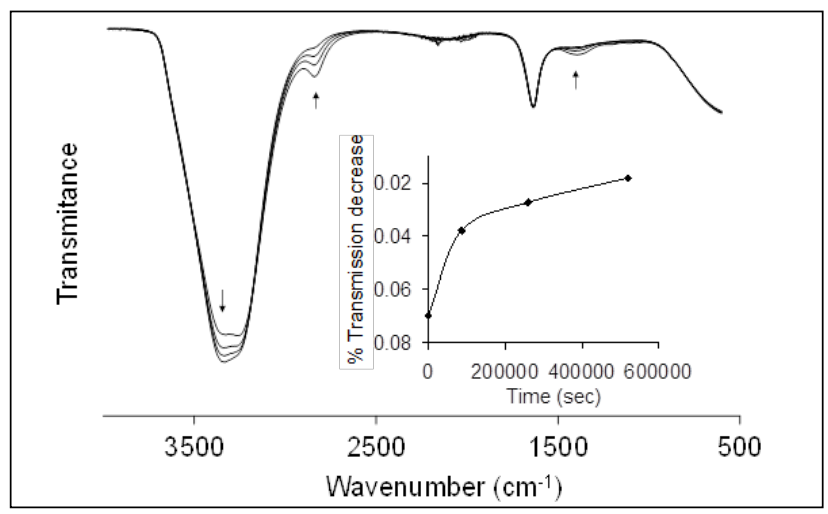

Figure 5

ATR FTIR spectra of a $2 \mathrm{M}$ solution of $\mathrm{H}_{2} \mathrm{O}_{2}$ decomposing in water at a $\mathrm{pH}$ of 9 . Insert: The time trace of the disappearance of the peak at $2860 \mathrm{~cm}^{-1}$.

Experiments A1, B1, C1 and D1, where the hydrogen peroxide concentration and amount of iron ore catalyst are kept constant while the concentration of the formic acid is being varied, indicated that the rate of decomposition also increases as the concentration of the formic acid increases (see Fig. 8). More formic acid molecules present in solution would lead to more interaction between the formic acid and the hydroxyl molecules which would in turn lead to a faster formic acid oxidation rate being observed.

In the next set of experiments, A1 and A7-9, the hydrogen peroxide and formic acid concentrations were kept constant while 
TABLE 3

Different experimental conditions of the wet oxidation of formic acid and their observed rate constants

\begin{tabular}{|c|c|c|c|c|c|}
\hline no & Amount of catalyst & {$\left[\mathrm{H}_{2} \mathrm{O}_{2}\right]$} & [formic acid] & $k_{\text {obs }} \times 10^{4} \mathrm{~min}^{-1}$ & TOF $\mathrm{s}^{-1}$ \\
\hline A1 & $50 \mathrm{mg}$ & $4 \mathrm{M}$ & $1.26 \mathrm{M}$ & $5.11(2)$ & $7.12 \times 10^{-8}$ \\
\hline A2 & $50 \mathrm{mg}$ & $6 \mathrm{M}$ & $1.26 \mathrm{M}$ & $6.24(2)$ & $7.12 \times 10^{-8}$ \\
\hline A3 & $50 \mathrm{mg}$ & $8 \mathrm{M}$ & $1.26 \mathrm{M}$ & $6.59(2)$ & $7.12 \times 10^{-8}$ \\
\hline A4 & $50 \mathrm{mg}$ & $10 \mathrm{M}$ & $1.26 \mathrm{M}$ & $8.78(1)$ & $7.12 \times 10^{-8}$ \\
\hline A5 & $50 \mathrm{mg}$ & $12 \mathrm{M}$ & $1.26 \mathrm{M}$ & $8.92(0.2)$ & $7.12 \times 10^{-8}$ \\
\hline A6 & $50 \mathrm{mg}$ & $15 \mathrm{M}$ & $1.26 \mathrm{M}$ & $12.00(3)$ & $7.12 \times 10^{-8}$ \\
\hline B1 & $50 \mathrm{mg}$ & $4 \mathrm{M}$ & $2.52 \mathrm{M}$ & $7.35(6)$ & $2.24 \times 10^{-7}$ \\
\hline C1 & $50 \mathrm{mg}$ & $4 \mathrm{M}$ & $6.3 \mathrm{M}$ & $9.87(2)$ & $5.60 \times 10^{-7}$ \\
\hline D1 & $50 \mathrm{mg}$ & $4 \mathrm{M}$ & $12.6 \mathrm{M}$ & $17.3(3)$ & $1.12 \times 10^{-6}$ \\
\hline A7 & $100 \mathrm{mg}$ & $4 \mathrm{M}$ & $1.26 \mathrm{M}$ & $10.00(1)$ & $3.36 \times 10^{-8}$ \\
\hline A8 & $150 \mathrm{mg}$ & $4 \mathrm{M}$ & $1.26 \mathrm{M}$ & $14.31(2)$ & $2.30 \times 10^{-8}$ \\
\hline A9 & $200 \mathrm{mg}$ & $4 \mathrm{M}$ & $1.26 \mathrm{M}$ & $21.75(3)$ & $1.73 \times 10^{-8}$ \\
\hline
\end{tabular}

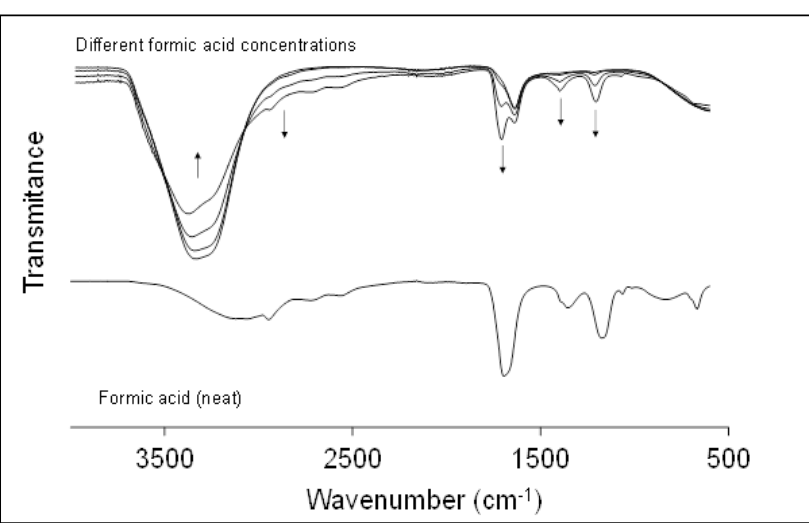

Figure 6

The ATR FTIR spectra of neat formic acid (bottom) and different concentrations $(2,4,6$ and $8 \mathrm{M}$ ) of formic acid dissolved in water at $\mathrm{pH}=2$ (top); the arrows indicate how the peaks would increase or decrease as the concentration of the formic acid is increased

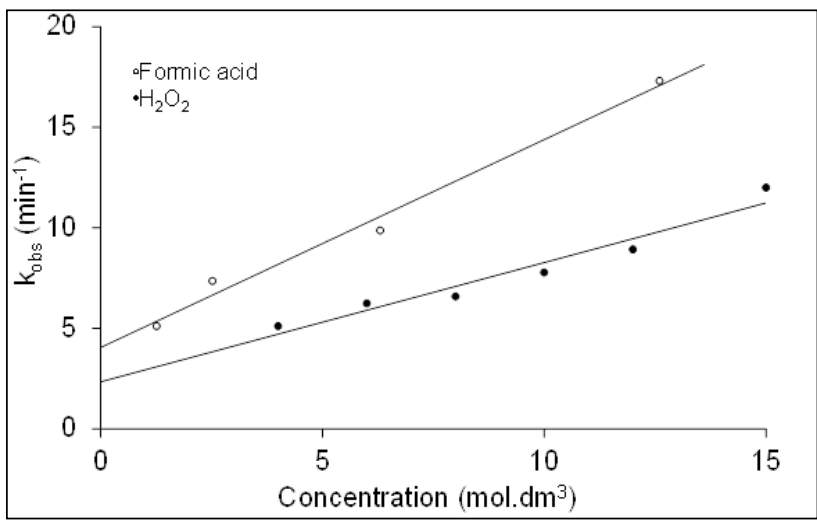

Figure 8

A graph illustrating the relationship between the concentration of both formic acid and hydrogen peroxide vs the observed rate constant $\left(k_{\text {obs }}\right)$ of the catalytic wet oxidation of formic acid

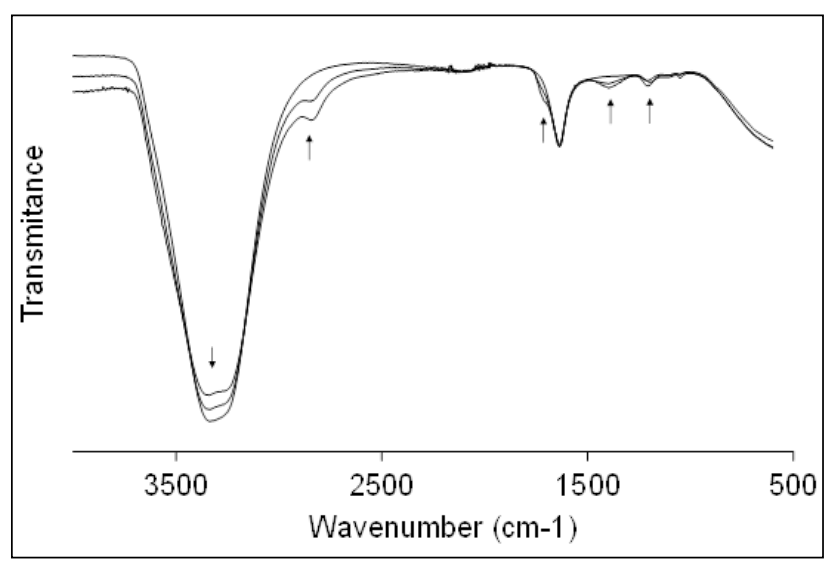

Figure 7

ATR FTIR spectra of the wet oxidation of an $8 \mathrm{M}$ formic acid solution by the decomposed products of a $2 \mathrm{M} \mathrm{H}_{2} \mathrm{O}_{2}$ in water mixture at a $\mathrm{pH}$ of 2 in the presence of $50 \mathrm{mg}$ naturally-occurring iron ore

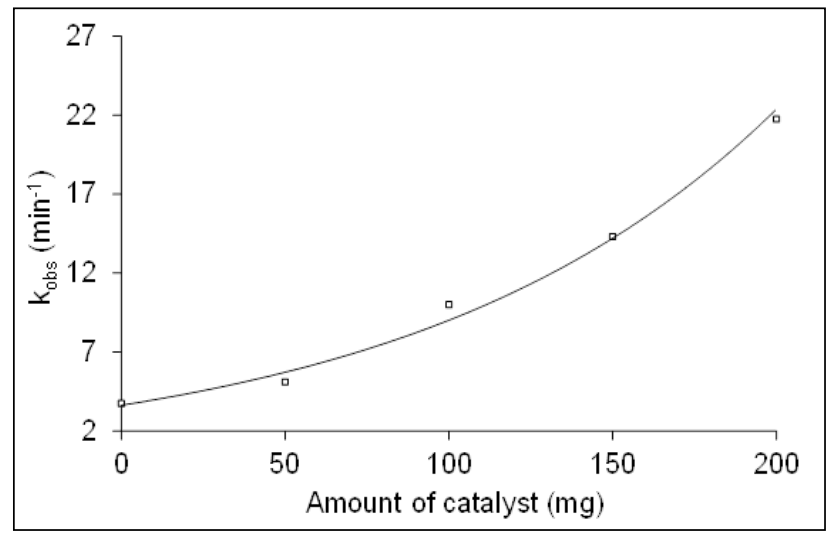

Figure 9

A graph illustrating the relationship between the amount of iron ore catalyst vs. the observed rate constant $\left(k_{\text {obs }}\right)$ of the catalytic wet oxidation of formic acid 
the amount of catalyst was varied (see Table 3). From Fig. 9, it can be seen that the observed rate constant for the catalytic wet oxidation of formic acid exponentially increases as the amount of catalyst increases.

\section{CONCLUSION}

It has been confirmed that formic acid can be effectively wet oxidized by the decomposed products of hydrogen peroxide over a naturally-occurring iron ore catalyst. The decomposition of hydrogen peroxide to its hydroxyl radicals ( $\mathrm{HO}^{*}$ and $\mathrm{HOO}^{*}$ ) is influenced by the $\mathrm{pH}$ of the solution. At higher $\mathrm{pH}$, hydrogen peroxide is more unstable and decomposition can occur spontaneously. At a constant $\mathrm{pH}$ of 2 , an increase in the concentration of hydrogen peroxide in aqueous solutions does not influence the rate of catalytic decomposition over naturally-occurring iron ore with an approx. $k_{\text {obs }}=1 \times 10^{-5} \mathrm{~min}^{-1}$ observed under the chosen experimental conditions.

The catalytic wet oxidation of formic acid by decomposed hydrogen peroxide radicals ( $\mathrm{HO}^{*}$ and $\mathrm{HOO}^{*}$ ) over naturallyoccurring iron ore indicated that higher levels of hydrogen peroxide and formic acid concentration result in higher formic acid oxidation rates. This can be attributed to increased amounts of reacting molecules present in solution.

\section{ACKNOWLEDGEMENTS}

The authors acknowledge the financial support provided by the University of the Free State.

\section{REFERENCES}

ALLEMANE H, DELOUANE B, PAILLARD H and LEGUBE B (1993) Drinking water treatment with ozone. Ozone Sci. Eng. 15 419-424. http://dx.doi.org/10.1080/01919512.1993.10555733

ANDREOZZI R, CAPRIO V and MAROTTA R (2003) Iron(III) (hydr) oxide-mediated photooxidation of 2-aminophenol in aqueous solution: a kinetic study. Water Res. 37 3682-3688. http://dx.doi. org/10.1016/S0043-1354(03)00271-9

ANDREOZZI R, INSOLA A, CAPRIO V, MAROTTA R and TUFANO $\mathrm{V}$ (1996) The use of manganese dioxide as a heterogeneous catalyst for oxalic ozonation in aqueous solution Appl. Catal. A: Gen. 138 75-81. http://dx.doi.org/10.1016/0926-860X(95)00247-2

BRION D (1980) Etude par spectroscopie de photoelectrons de la degradation superficielle de FeS2, CuFeS2, ZnS et PbS a l'air et dans l'eau. Appl. Surf. Sci. 5 133-152. http://dx.doi. org/10.1016/0378-5963(80)90148-8

BUTTERFIELD IM, CHRISTENSEN PA, HAMNETT A, SHAW KE, WALKER GM, WALKER SA and HOWARTH CR (1997) Applied studies on immobilised titanium dioxide films as catalysts for photoelectrochemical detoxification of water. J. Appl. Electrochem. 27 385-395. http://dx.doi.org/10.1023/A:1018453402332

CANDAL RJ, ZELTNER WA and ANDERSON MA (1997) Titanium-supported titania photoelectrodes made by sol-gel processes. J. Environ. Eng. 125 906-912. http://dx.doi.org/10.1061/ (ASCE)0733-9372(1999)125:10(906)

CASTANEDA CM, ASHBAUGH L and WAKABAYASHI P (2010) Use of proton backscattering to determine the carbon and oxygen content in fine particle samples deposited on $\operatorname{PTFE}((\mathrm{CF} 2)(\mathrm{n}))$ membrane disk filters. J. Aerosol Sci. 41 99-107. http://dx.doi.org/10.1016/j. jaerosci.2009.08.011

CENTI G, PERATHONER S, TORRE T and GRAZIA VERDUNA M (2000) Catalytic wet oxidation with $\mathrm{H} 2 \mathrm{O} 2$ of carboxylic acids on homogeneous and heterogeneous Fenton-type catalysts. Catal. Today 55 61-69. http://dx.doi.org/10.1016/S0920-5861(99)00226-6

CLAUDEL B, NUEILATI M and ANDRIEU J (1984) Oxidation of formic-acid in aqueous-solution by palladium catalysts. Appl. Catal. 11 217-225. http://dx.doi.org/10.1016/S0166-9834(00)81880-1
CHOU S, HUANG Y-H, LEE S-N, HUANG G-H and HUANG C (1998) Treatment of high strength hexamine-containing wastewater by electro-Fenton method. Water Res. 33 751-759. http://dx.doi. org/10.1016/S0043-1354(98)00276-0

COSTA RCC, MOURA FCC, ARDISSON JD, FABRIS JD and LAGO RM (2008) Highly active heterogeneous Fenton-like systems based on $\mathrm{Fe} 0 / \mathrm{Fe}_{3} \mathrm{O}_{4}$ composites prepared by controlled reduction of iron oxides. Appl. Catal., B: Environ. 83 131-139. http://dx.doi. org/10.1016/j.apcatb.2008.01.039

DAVIS AP and GREEN DL (1999) Photocatalytic oxidation of cadmium-EDTA with titanium dioxide. Environ. Sci. Technol. 33 609-617. http://dx.doi.org/10.1021/es9710619

DINSDALE RM, HAWKES FR and HAWKES DL (2000). Biodegradation of short organic acids in an expanded granular sludge bed reactor. Water Res. 34 2433-2438. http://dx.doi.org/10.1016/ S0043-1354(99)00430-3

DU W, XU Y and WANG Y (2008) Photoinduced degradation of orange II on different iron (hydr)oxides in aqueous suspension: Rate enhancement on addition of hydrogen peroxide, silver nitrate, and sodium fluoride. Langmuir 24 175-181. http://dx.doi.org/10.1021/ la7021165

EDWARDS JO and CURCI R (1992) Catalytic Oxidations with Hydrogen Peroxide as Oxidant. Kluwer, Dordrecht.

ESPENSON JH (1995) Chemical Kinetics and Reaction Mechanisms ( $2^{\text {nd }}$ edn). McGraw-Hill, New York.

GALLEZOT P, CHAUMET S, PERRARD A and ISNARD P (1997) Catalytic wet air oxidation of acetic acid on carbon-supported ruthenium catalysts J. Catal. 168 104-109. http://dx.doi.org/10.1006/ jcat.1997.1633

GIGUERE PA (1950) The infra-red spectrum of hydrogen peroxide J. Chem. Phys. 18 88-92. http://dx.doi.org/10.1063/1.1747464

GUO H, STÜBEN D and BERNER Z (2007) Removal of arsenic from aqueous solution by natural siderite and hematite. Appl. Geochem. 22 1039-1051. http://dx.doi.org/10.1016/j.apgeochem.2007.01.004

HABER J, STOCH J and UNGIER L (1976) X-ray photoelectron spectra of oxygen in oxides of $\mathrm{Co}, \mathrm{Ni}, \mathrm{Fe}$ and $\mathrm{Zn}$ J. Electron Spectrosc. Relat. Phenom. 9 459. http://dx.doi.org/10.1016/0368-2048(76)80064-3

HARMSEN JMA, JELEMENSKY L, VAN PJM, KUSTER BFM and MARIN GB (1997) Kinetic modeling for wet air oxidation of formic acid on a carbon supported platinum catalyst Appl.Catal. A. 165 499-509. http://dx.doi.org/10.1016/S0926-860X(97)00232-9

HUANG HH, LU MC and CHEN JN (2001) Catalytic decomposition of hydrogen peroxide and 2-chlorophenol with iron oxides. Water Res. 35 2291-2299. http://dx.doi.org/10.1016/S0043-1354(00)00496-6

HWANG D-S, LEE E-H, KIM K-W, LEE K-I and PARK S-J (1999) Denitration of simulated high-level liquid waste by formic acid. J. Ind. Eng. Chem. 5 45-51.

KAWAGUCHI H (1993) Photo-oxidation of formic acid in aqueous solution in the presence of hydrogen peroxide. Chemosphere $\mathbf{2 6}$ 1965-1970. http://dx.doi.org/10.1016/0045-6535(93)90023-X

KIM DH, ANDERSON MA (1996) Solution factors affecting the photocatalytic and photoelectrocatalytic degradation of formic acid using supported $\mathrm{TiO}_{2}$ thin films J. Photochem. Photobiol. 94 221-229. http://dx.doi.org/10.1016/1010-6030(95)04178-8

KLINGHOFFER AA, CERRO RL, ABRAHAM MA (1998) Catalytic wet oxidation of acetic acid and using platinum on alumina monolith catalyst Catal. Today 40 59-71. http://dx.doi.org/10.1016/ S0920-5861(97)00122-3

KYOTANI T, NAGAI T, INOUE S, TOMITA (1997) Formation of new type of porous carbon by carbonization in zeolite nanochannels Chem. Mater. 9 609-615. http://dx.doi.org/10.1021/cm960430h

LEVEC J, PINTAR A (1995) Catalytic-Oxidation of Aqueous Solutions of Organics - An Effective Method for Removal of Toxic Pollutants From Watse-Water Catal. Today 24 51-58. http://dx.doi. org/10.1016/0920-5861(95)00006-2

LI Y-S (1999) The use of waste basic oxygen furnace slag and hydrogen peroxide to degrade 4-chlorophenol. Waste Management 19 495-502. http://dx.doi.org/10.1016/S0956-053X(99)00239-1

LUCK F, DJAFER M, LEITNER NKV, GOMBERT B and LEGUBE B (1997) Destruction of pollutants in industrial rinse waters by advanced oxidation processes. Water Sci. Technol. 35 287-292. http:// dx.doi.org/10.1016/S0273-1223(97)00037-1 
LUCK F (1996) A review of industrial catalytic wet air oxidation processes. Catal. Today 27 195-202. http://dx.doi. org/10.1016/0920-5861(95)00187-5

MASTEN SJ and DAVIES SHR (1994) The use of ozonization to degrade organic contaminants in wastewaters. Environ. Sci. Technol. $28181-$ 185. http://dx.doi.org/10.1021/es00053a001

MATATOV-MEYRAL YI and SCHEINTUCH M (1998) Catalytic abatement of water pollutants. Ind. Eng. Chem. Res. 37 309-326. http:// dx.doi.org/10.1021/ie9702439

MISHRA VS, MAHAJANI VV and JOSHI JB (1995) Wet air oxidation. Ind. Eng. Chem. Res. 34 2-48. http://dx.doi.org/10.1021/ie00040a001

MILLER LW, TEJEDOR-TEJEDOR MI and ANDERSON MA (1999) Titanium dioxide-coated silica waveguides for the photocatalytic oxidation of formic acid in water. Environ. Sci. Technol. 33 2070-2075. http://dx.doi.org/10.1021/es980817g

MOULDER F, STICKLE WF, SONOL PE and BOMBEN KD (1995) Handbook of X-ray Photoelectron Spectroscopy. ULVAC-PHI, Inc. Japan, Chigasaki.

NEFEDOV VI, GATI D, DZHURINSKII BF, SERGUSHIN NP and SALYN YV (1975) Simple and coordination compounds. Zh. Neorf. Khimii. 20 2307-2314.

NOWACK B, STONE AT (2006) Competitative adsorption of phosphate and phosphonates onto goehite. Water Res. 40 2201-2209. http:// dx.doi.org/10.1016/j.watres.2006.03.018

OJIMA S, ABE M and YAMAKI Y (1994) A new system for high-purity water production. Ultrapure Water 11 45-48.

OGATA Y, TOMIZAWA K, TAKAGI K (1981) Photooxidation of formic, acetic, and propionic acids with aqueous hydrogen peroxide. Can. J. Chem. 59 14-18. http://dx.doi.org/10.1139/v81-003
PIRILLO S, FERREIRA ML, RUEDA EH (2009) The effect of pH in the adsorption of alizarin and eriochrome blue black $\mathrm{R}$ onto iron oxides. J. Hazardous Mater. 168 168-178. http://dx.doi.org/10.1016/j. jhazmat.2009.02.007

ROVIRA M, GIMENEZ J, MARTINEZ M, MARTINEZ-LLADO X, PABLO J, MARTI V, DURO L (2008) Sorption of selenium(IV) and selenium(VI) onto natural iron oxides: Geothite and hematite. J. Hazardous Mater. 150 279-274. http://dx.doi.org/10.1016/j. jhazmat.2007.04.098

ROMALHO RS (1983) Introduction to Wastewater Treatment Processes ( $2^{\text {nd }}$ edn). Academic Press Publisher, New York.

SPITERI C, CAPPELLEN PV and REGNIER P (2008) Surface complexation effects on phosphate adsorption to ferric iron oxyhydroxides along $\mathrm{pH}$ and salinity gradients in estuaries and coastal aquifers. Geohim. Cosmochim. Acta 72 3431-3445. http://dx.doi.org/10.1016/j. gca.2008.05.003

WALLIN GC (1975) Fenton's reagent revisited. Acc. Chem. Res. 8 125-131. http://dx.doi.org/10.1021/ar50088a003

WILSON MGC and ANHAEUSSER CR (1998) The Mineral Resources of South Africa, Handbook 16 ( $\left.6^{\text {th }} \mathrm{edn}\right)$. Council for Geoscience, Pretoria.

ZENG L, LI X and LIU J (2004) Adsorptive removal of phosphate from aqueous solutions using iron oxide tailings. Water Res. 38 1318-1326. http://dx.doi.org/10.1016/j.watres.2003.12.009

ZHANG W, SINGH P, PALING E and DELIDES S (2004) Arsenic removal from contaminated water by natural iron ores. Miner. Eng. 17 517-524. http://dx.doi.org/10.1016/j.mineng.2003.11.020 